\title{
Knowledge Sharing, Absorptive Capacity and Innovation Capabilities: An Empirical Study on Small and Medium Enterprises in North Sulawesi, Indonesia
}

\author{
Nikolas Fajar Wuryaningrat \\ Faculty of Economy Manado State University, Indonesia
}

\begin{abstract}
The capability of a firm to instill innovation depends on its knowledge resources. This capability can be utilized by facilitating knowledge sharing and absorptive capacity in the context of small and medium enterprises. The purpose of this research is to examine how knowledge sharing can be transformed into innovation capabilities. Research suggests that knowledge sharing will first influence absorptive capacity before knowledge can be transformed to innovation capabilities. This research was conducted in North Sulawesi which has excellent economic growth by involving small and medium enterprises. The results show that knowledge donating and knowledge collecting positively influence SME's innovation capabilities if absorptive capacity is also developed. In other words, the result of the research gives us empirical evidence that new knowledge created from knowledge sharing can be transformed into innovation capabilities if it is supported by higher absorptive capacity.
\end{abstract}

Abstract: Kemampuan perusahaan untuk berinovasi tergantung pada sumber-daya pengetahuan. Kemampuan ini dapat dimanfaatkan dengan memfasilitasi berbagi pengetahuan dan daya-serap dalam konteks usaha kecil dan menengah. Tujuan dari penelitian ini adalah untuk mengkaji bagaimana berbagi pengetahuan dapat diubah menjadi kemampuan inovasi. Penelitian menunjukkan bahwa berbagi pengetahuan terutama akan mempengaruhi daya-serap sebelum pengetahuan dapat diubah menjadi kemampuan inovasi. Penelitian ini dilakukan di Sulawesi Utara yang memiliki pertumbuhan ekonomi yang sangat baik dengan melibatkan usaha kecil dan menengah. Hasil menunjukkan bahwa pengetahuan dan pengetahuan menyumbangkan mengumpulkan berpengaruh positif terhadap kemampuan inovasi UKM jika kapasitas serap juga dikembangkan. Dengan kata lain, hasil penelitian memberikan bukti empiris bahwa pengetahuan baru yang dibuat dari berbagi pengetahuan dapat diubah menjadi kemampuan inovasi jika didukung oleh daya serap tinggi.

Keywords: absorptive capacity; innovation capability; knowledge donating; knowledge collecting; knowledge sharing 


\section{Introduction}

The global economy has created a business environment with high-level competition so a firm should have sustainable competitive advantage, and has to be able to maintain it. Innovation is a way a small or large enterprises can create and maintain sustainable competitiveness (Johannesen et al. 2001). The capability of a firm to produce innovative commercial ends depends on its ability to manage its knowledge resources (Darroch 2005). According to Darroch (2005), a firm which is able to manage its knowledge resources more effectively will eventually be able to transform into a more innovative firm. Hence, knowledge in the organization needs to be managed and be well rewarded in order to ensure the success of innovation (Du Plessis 2007). A lot of literature and studies focusing on knowledge management have shown us that knowledge sharing and absorptive capacities are interesting, critical issues to be considered.

Many previous studies have pointed out that knowledge sharing and absorptive capacity are the fundamental parts in the effort to improve innovation capabilities of a firm (see, Liao et al. 2007; Lin 2007; Tsai 2001). However, these studies have frequently regarded the knowledge sharing and absorptive capacity as two variables having direct influence on the innovation capabilities. In my opinion, thus, absorptive capacity has more function as the partially intervening variable on the influence of knowledge sharing on innovation capabilities instead of having a direct effect. This opinion is based on Davenport and Prusak (1998) who state that knowledge sharing must be supported by ca- pability to absorb knowledge; otherwise, that knowledge will not be completely transferred. Liao et al. (2006) also support this opinion because they explain that knowledge sharing has a positive impact improving absorptive capacity. After its absorptive capacity greatly improves, the firm uses any knowledge it gets to create innovative commercial ends.

This research focuses on the SMEs sector because the exploration of this sector is a new topic to discuss because few researches have focused on. Despite its various disadvantages, such as the lack of capital and human resources, SMEs have various advantages too, for example, simple organizational structure, small number of workers, and little involvement in the bureaucracy. Those advantages are an important factor for SMEs to optimize their knowledge resources (Ayyagari 2006).

Therefore, this research aims to fill the gaps in the previous studies. It is expected that the study will leads to better understanding about the issue of the importance of knowledge sharing for improving absorptive capacity and innovation capabilities of SMEs. Further, this research was conducted based on the research model of Liao et al. (2006). This model regards absorptive capacity as an independent and mediating variable. Even though this research is grounded upon Liao et al. (2006), there are slight differences between these two researches. First, this research only treats absorptive capacity as a mediating variable. Second, this research is conducted based on the explanation of Hoof and Ridder (2004) that knowledge sharing dimensions (knowledge donating and knowledge collecting) are distinguished variables. Therefore, this research regards these

\footnotetext{
${ }^{1}$ It is assumed that absorptive capacity is not the only variable being able to mediate the influence of knowledge sharing on the innovation ability. There are some other influencing variables such as knowledge stickiness (Szulanski 1996), team culture (Hu et al. 2009) and others.
} 
variables as two distinctive variables instead of single variable as with Liao et al. (2006) in their research. In other words, the separation of two variables differentiates this research from the previous one. Further, this research is conducted as the effort to make correction on the previous one.

This article will be divided into four parts. The first part discusses the theories of knowledge sharing, absorptive capacity, innovation and relevant empirical findings as well as hypotheses development. The second part contains the detailed information on the research method applied in this research. The final part consists of discussion, conclusion, limitation and suggestion for future research.

\section{Literature Review and Hypothesis Development}

\section{Innovation as Newness}

Nowadays, innovation has evolved into a fundamental part of the firm's life in order to demonstrate its ability in terms of competitiveness, and to serve as the key to success (Nonaka and Takeuchi 1995). Tidd et al. (2005) also explain in order to survive in the competition, all large and small firms need innovation.

According to Schumpeter (in Tidd et al. 2005), innovation has become the inseparable part of the entrepreneurial spirit which always tries to seek innovative methods in order to gain strategic advantage. Therefore, the innovations nowadays are considered to be a fundamental part of the entrepreneurship and a key element of business success (Pirich et al. 2001; Covin and Miles 1999). Entrepreneurial spirit is the soul of a visionary having the imaginative ability and creat- ivity. This ability becomes the underlying factor in making innovation. In order words, on-going innovation reflects renewable developing of the entrepreneurship spirit.

Innovation has various definitions, but those definitions lead to one conclusion, that is, innovation is a form of newness. Johannessen et al. (2001) define innovation as a form of newness which aims to create and maintain a sustainable competitive advantage. According to Johannessen et al. (2001), as a form of newness, innovation can be seen from these three questions, namely: What is new? How is it new? And to whom is it newness?

As a matter of fact, innovation is not solely limited to tangible objects but also processes. According to Samson (1991, in Harrison and Samson 2002), newness is divided into three types, those are: product innovation, process innovation, and managerial and system innovation. Furthermore, Damanpour (1996) classifies innovation into several categories, such as new product or service innovation, organizational structures or administrative systems, new technologies, new plant or a new program for members of the organization. Damanpour (1996) and Johanessen et al. (2001) explain that the measurement of innovation can be seen from six types of innovations, those are, innovation as new products, new method of production, new services, opening new markets, new sources of supply, and new ways of organizing.

Newness in innovation lies in the degree of newness. Regarding this degree of newness, Tidd et al. (2005) reveal that the level of innovation can be divided into two terms, namely, incremental innovation and continuum of radical innovation. Incremental innovation refers to an action of enhancing or upgrading the existing model, and intro- 
duces this modified model as something new for the company. Meanwhile, radical innovation refers to an action of making a breakthrough which is very different from the existing model, so it emerges as a completely new product.

Similar as Tidd et al. (2005), March (1991) divides innovation into two categories: exploitative and exploratory innovation. Exploitative innovation refers to the efforts that the firm has initiated to develop or modify the existing innovation (eg: modification of packaging products). Meanwhile, exploratory innovation refers to the efforts of the firm in pursuing fresh innovation that is greatly different from the existing product. Exploratory Innovation has greater risk than exploitative innovation (March 1991). Despite the risks embedded in every kind of innovation, the most effective way in determining the success of innovation in one firm lies in the combination of both types of innovation (Kamasak and Bulutlar 2009).

Both incremental and radical changes often occur in the activity of the firm. Those changes can sometimes be accepted and are integrated into the firm's daily activities; however, those changes seem to be very radical and lead to fundamental changes for the firm (Tidd et al. 2005).

The following illustration can be a perfect example of how changes can be very radical. When a SME applies the use of information technology to its production processes, this change is regarded as a new thing for the firm. On the other hand, the use of information technology for larger companies is probably very common. In other words, innovations as newness are closely related to where that innovation is adopted. Hence, a form of newness in one firm will be different from other companies. Tidd et al. (2005) explains that the newness of the innovation depends on the perception of its creator or the firm.

\section{Knowledge Sharing}

According to Kamasak Bulutlar (2009), knowledge sharing is associated with knowledge creation. Nonaka et al. (2006) define knowledge creation as a continuous learning process by acquiring a new context, new insights and new knowledge.

Knowledge sharing is a social activity (Dalkir 2005). Therefore, to gain new knowledge, individuals require interaction and communication about its tacit and explicit knowledge with other individuals (Kamasak and Bulutlar 2009).

The learning process establishes important meaning when the knowledge gained is not kept inside; instead, it is shared to other persons. Grant (1996) supports this argument since he states that knowledge as a resource should have the characteristics of "transferability", and knowledge-sharing represents this characteristic. Srivastava et al. (2006) underlines that knowledge will be underutilized until it is shared.

Knowledge sharing can be defined as the process of mutual knowledge exchange among individuals either tacitly or explicitly in the attempt to create new knowledge (Hoof and Ridder 2004). Knowledge sharing includes several activities, such as giving ideas, suggestions, advice, information, experience and expertise to other team members in the organization (Bartol and Srivastava 2002).

According to Van den Hoof and Rider (2004), knowledge sharing is divided into two different dimensions, namely, knowledge donating and knowledge collecting. Knowledge donating is the process of bringing or pro- 
viding knowledge through communication between individuals. Knowledge collecting is defined as the process of obtaining knowledge from other individuals via a consultation or to persuade and invite other individuals to be willing to share their knowledge (Hoof and Ridder 2004).

Knowledge sharing does not only involve the interaction among individuals in the organization but also with individuals outside organizations (Sveiby 2001). Yeh et al. (2010) explain that in a market-oriented organization, someone can do knowledge sharing with other persons from another department, with customers, and with competitors. Dyer and Nobeoko (2000) explain that Toyota achieves its optimum productivity by building a knowledge sharing network with its suppliers. Based on the opinions above, knowledge sharing is expected to be the key in translating individual learning into organizational capabilities to improve the competitiveness (Frey and Oberholzer-Gee 1997; Nahapiet and Ghoshal 1998; in Lam and Lambermont-Ford 2008). Chaudhry (2005) also elucidates a similar opinion that effective knowledge sharing practices should be able to generate and utilize knowledge from individual to organizational level.

\section{Absorptive Capacity}

Knowledge sharing will be effective if supported by absorptive capacity. At the beginning of their article, Davenport and Prusak (1998) state that knowledge will not be completely transferred without the support from absorptive capacity. Similarly, Szulanski (1996) reveals knowledge transfer in one firm will emerge as a big obstacle without the support of absorptive capacity. Therefore it can be concluded that knowledge sharing and absorptive capacity are inseparable parts in the discussion.
Zahra and George (2002) in Indarti (2010) disclose that absorptive capacity is a set of organizational routines necessary to identify and utilize knowledge. Referring to broader perspective on macroeconomics, absorptive capacity refers to the ability of an economy to utilize and absorb information sources (see, Indarti 2010). Cohen and Levinthal first introduced absorptive capacity to organizations.

Cohen and Levinthal (1990) define absorptive capacity as a firm's ability to assess new knowledge from outside, assimilate, and apply it for commercial ends. The mechanism underlying the assessment and assimilation of new knowledge is learning. Further, Indarti (2010) mentions that innovation is the result of learning process.

Liao et al. (2006) explains that there are two factors that affect the absorptive capacity. The first factor affecting this capacity is the motivation and ability of employees. Research conducted by Liao et al. (2006) provides empirical evidence that innovation results from the needs for knowledge sharing because of its ability to improve absorptive capacity. When absorptive capacity improves, it would be much easier for someone to create remarkable innovation based on knowledge gained. Indarti (2010) also mentions that absorptive capacity can be regarded as a process through which a particular firm creates innovative commercial ends.

\section{Knowledge and Its Relevance to the SMEs}

It is believed that knowledge is the most important resource for an organization to achieve its competitive advantage (Davenport and Prusak 1998; Grant 1996; Nonaka and Takeuchi 1995). Nowadays, knowledge plays a role in all kinds of business contexts and 
organizations including small and medium business.

SMEs are known as having 'one man show' management because it comprises one person serving as either the owner or manager. Hence, the development of knowledge starts from its owners or managers (Indarti 2010). Thus, both the owners and managers of SMEs possess the highest responsibility for developing and sharing the knowledge with others. In addition, they are also responsible for motivating employees to actively participate in giving new ideas relevant to solving problems and to ensure organizational change (e.g. innovation) (Yukl 2006).

Knowledge plays an important role in all kinds of business including SMEs; however, many SMEs in developing countries face various problems. One of these problems lies on their restricted access to market, knowledge, financial and institutional support (Mead and Liedhom 1998). Wuryaningrat (2012), in his research conducted on many manufacturing SMEs in the Special Province of Yogyakarta, has found that knowledge sharing, such as knowledge collecting, has negative impacts on innovation capabilities that SMEs might have. He further explains that the lack of capital, human resources and the use of information technology become the major elements of knowledge that SMEs are unable to absorb entirely.

Even though SMEs face many problems, such as the lack of capital, of reliable labor, and of technology used, they have great potential to continue developing their innovation capabilities through knowledge resources. SMEs having small number of employees, simple organizational structure and little involvement with bureaucracy, will be able to absorb and disseminate knowledge (knowledge sharing) to the organization which in turn can also possibly enhance
SMEs innovation capabilities (Ayyagari 2006; Pelham 2000). Hence, SMEs require greatly abundant access to knowledge. Indarti (2010), in her dissertation, mentions that the more a firm has access to knowledge, the more possible that firm can be a success.

In the early decades of the twentieth century, Joseph Schumpeter (1934 1942) mentioned the process of creative destruction, whereby the continual creation of new ideas by innovative firms steadily destroys the positions of stagnant firms. Acz et al. (1997) mention that small and medium businesses play an important role in the process of creative destruction. He argued that a larger firm cannot be regarded as an innovative firm without the support of SMEs. This larger firm appears to be more dominant in its innovative activities; however, these innovative activities mostly occur in smaller firms (Acs et al. 1997; Barney 2007). Hence, smaller firms are the innovators in more innovative industries (Acs et al. 1997).

A large scale firm indeed has more access, for example, funding and better human resources, than SMEs sector (Rogers 2003); however, a larger firm also still faces problems on innovation capabilities that still need solving. A larger company faces more complex organizational structure and becomes deeply involved in bureaucracy which eventually becomes its major obstacle in optimizing its use of knowledge see Barney 2007; Acs et al. 1997). Davenport and Prusak (1998) also explain that knowledge development depends the size of the firm.

\section{Knowledge Sharing, Absorptive Capacity and Innovation Capabilities}

The outline of absorptive capacity can be analyzed through knowledge sharing 
framework. Nowadays, knowledge sharing is believed to be fundamental for a firm optimizing its knowledge resources. A lot of credible literature about knowledge management also states that knowledge sharing is the most critical issue in the optimization of knowledge resources. Nonetheless, knowledge sharing means nothing without adequate absorptive capacity (see Davenport and Prusak 1998; Srivastava et al. 2006). By conducting knowledge sharing, it is expected that someone will have a broader understanding why firm needs absorptive capacity and how the firm organizes this capacity (Indarti 2010).

As mentioned in previous section, knowledge sharing is a learning process drawing from many sources. Knowledge sharing is a learning process conducted in internal and external environments to gain new knowledge (Sveiby 2001). Thus, the final goal of this learning process is improved absorptive capacity. Higher intensity of knowledge sharing conducted in the firm can increase the ability remarkably to absorb knowledge itself (Liao et al. 2006). Tsai (2001) also reveals that knowledge sharing among business units provides broader understanding and learning which enables one business unit to create innovation. In other words, knowledge sharing is a learning process that aims at not only gaining new knowledge but also learning the mutual understanding on the new knowledge. Thus, it is expected that the results of the learning process are able to gradually increase the ability to absorb knowledge.
When the ability to absorb knowledge develops, one organization will have better ability to replicate, acquire, and apply knowledge. If SMEs can absorb more knowledge from their business environment, SMEs will have the opportunity to increase knowledge resources. With abundant knowledge, it is possible for SMEs to create many innovative commercial ends. This opinion is supported by previous research which was conducted by Indarti (2010). Which reveals that the fruit of the SMEs absorptive capacity is the increase in SMEs innovation capabilities.

From the explanation, some hypotheses can be drawn out.

H1a. The higher the intensity of knowledge donating, the more likely the firms have better absorptive capacity

H1b. The higher the intensity of knowledge collecting, the more likely the firms have better absorptive capacity

H2. The higher the intensity of knowledge sharing, the more likely the firms have better absorptive capacity which in turn lead to bigher innovation capability

\section{Research Model}

Based on the discussion about theory and hypothesis development that has been described previously, one research model can be formulated and seen in Figure 1. 
Figure 1. Research Model

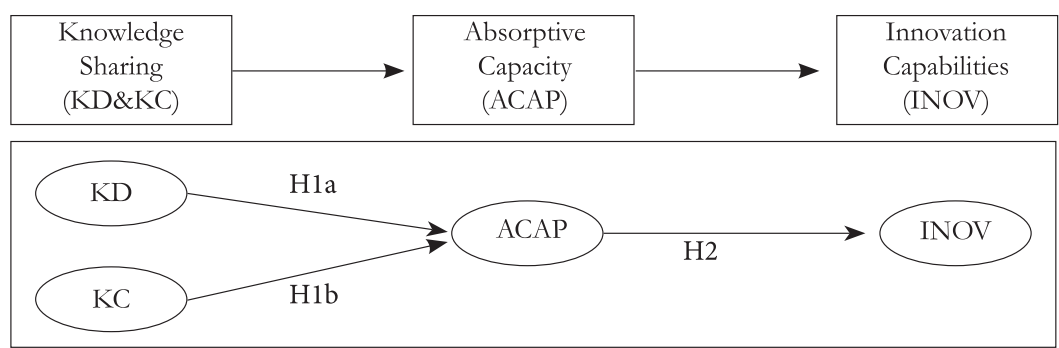

Note: KD: knowledge donating, KC:knowledge collecting, ACAP:absorptive capacity, INOV: innovation capabilities

\section{Methodology}

The researches was conducted in North Sulawesi due to its fascinating development. North Sulawesi is regarded as one of the regions experiencing the highest economic growth.' According to data gained from North Sulawesi Statistical Bureau, the economic growth in North Sulawesi during the first semester of 2012 has increased by 7.49 percen if compared to the first semester of 2011. The economic growth of North Sulawesi;s economy is even higher than Indonesia's economy growth which is only 6.3 percen. In interviews with several media in North Sulawesi, Indonesian Minister of Cooperatives and SMEs, Syarifuddin Hasan, said that the success of the national economy growth including North Sulawesi cannot be separated from the contribution of SMEs (ManadoGO.com). The economic progress in the Province of North Sulawesi which is supported by the development of innovative SMEs and represents one example of the success in the embodiment of creative economy in North Sulawesi. The cultural uniqueness of North Sulawesi, sitou tumou tou, which means "sharing, giving respect to others, and giving help", makes this area become an interesting topic to explore. Davenport and Prusak (1998) explain that the cultural similarities play an important role in encouraging a person to share knowledge.
This research uses an explanatory research design by applying a survey approach. This method enables research findings to be generalized across persons, settings, and time (Cooper and Schlinder 2008; Kerlinger and Lee 2000). However, this research faces obstacles because the data gained from SMEs agencies of North Sulawesi Province do not reflect the reality. Therefore, to gain more credible data, this research involves non random purposive sampling techniques. Samples taken must meet the following criteria: 1). SMEs must have been established for a minimum of three years because this length of time is assumed to give sufficient time for delivery and introduction of SME innovation (see, Rogers 2003). 2). SMEs must have less than 100 employees (Indonesia statistic bureau or BPS). 3). SMEs are in the manufacturing sector because the innovation measurement used in this research is suitable for manufacturing industry SMEs.

Data were analyzed with a based on variant or PLS-SEM using SmartPLS 2.0 M3 software for efficiency and practical reasons. PLS-SEM is a multivariate technique combining aspects of multiple regression and factor analysis to examine the relationship theory simultaneously and has good statistical power despite the small sample size and is robust in the face of problems of classical assumptions (Hair et al. 2011). PLS applies 
bootstrapping techniques to test the hypothesis. It can be said that the hypothesis is valid if the value of $\mathrm{t}$-statistic $\geq 1.96$ two-tailed ( $\mathrm{p}$ value $5 \%$ ) and this value has a direct relationship with the hypothesis.

The test on mediating effect does not only measure the effect of direct relationship between independent and dependent variables but also measures the effect of indirect relationship between them by using a mediating variable (Baron and Kenny 1986). Baron and Kenny (1986) argue that the mediating effect has three characteristics. First, the main effect between independent and dependent variables must be significant. Second, the relationship between independent variable and mediating variable must be significant. Finally, the main effect will no longer be significant or less significant due to the decreasing coefficient value of the direct effect after the simultaneous test on the main effect between independent variable on dependent variable and mediating variable on dependent variable is conducted. If the result is no longer significant, this condition is regarded as fully mediated. On the contrary, the decrease in the value coefficient is called partially mediated.

\section{Measurement}

The statements in the closed questionnaire use the Likert scale 1 to 5 ( $1=$ very rarely to $5=$ very often/almost always) to indicate the respondents' intensity level for answer choices. Respondents in this study are the owners or managers of SMEs because they are the main actors having the most important roles and responsibilities for the development and innovation of their firms (Stanworth and Curran 1976 cited in Indarti 2010). In other words, the owners or managers of SMEs serve as the main agent in developing innovative and creative SMEs. Thus, the embodiment of creative economy is the responsibility of the owner. Table 1 provides information on construct definitions, dimensions, instruments used and the item numbers in the questionnaire.

Table 1. Construct and Their Measurement

\begin{tabular}{|c|c|c|c|c|}
\hline Variable & Definition & Dimensions & Measurement & $\begin{array}{c}\mathrm{n} \\
\text { item } \\
\end{array}$ \\
\hline Knowledge Sharing & $\begin{array}{l}\text { the process of in- } \\
\text { dividual mutually ex- } \\
\text { change their tacit or } \\
\text { explicit knowledge } \\
\text { and jointly to create } \\
\text { new knowledge. }\end{array}$ & $\begin{array}{l}\text { Knowledge donating } \\
\text { and knowledge col- } \\
\text { lecting }\end{array}$ & $\begin{array}{l}\text { Hooff and } \\
\text { Ridder (2004). } \\
\text { Reflective. }\end{array}$ & 10 \\
\hline Absorptive Capacity & $\begin{array}{l}\text { firm's ability to as- } \\
\text { sess new knowledge } \\
\text { from outside, as- } \\
\text { similate, and apply it } \\
\text { for commercial ends }\end{array}$ & $\begin{array}{l}\text { Employee motivation } \\
\text { and ability }\end{array}$ & $\begin{array}{l}\text { Liao et al. } \\
(2006) \\
\text { Reflective. }\end{array}$ & 8 \\
\hline
\end{tabular}


Table 1 (Continued)

\begin{tabular}{llll}
\hline Innovation & Innovation as a & New products, new & Johannessen \\
Capabilities & newness to make & method of produc- & et al. (2001). \\
& sustainable competi- & tion, new services, & Reflective. \\
& tive advantage & opening new markets, & \\
& new sources of sup- & \\
& ply, and a new ways & \\
& of organizing & \\
&
\end{tabular}

This research instrument was adopted from the original version of questionnaires in English language from previous studies. Then, it is translated into Indonesian language using back-translation method in order to avoid discrepancies. After being translated, this draft of the survey instrument was reviewed by a panel of academics and practitioner experts in the field of entrepreneurship or SMEs for its content, clarity, and understanding. The review was first conducted by experienced lecturers and then SME practitioners. After all comments were reviewed, the survey instrument was modified accordingly. After undergoing tight and detailed review, the data gained from the answers of respondents are regarded as valid and good data. To ensure data validity, convergent validity, discriminant validity and internal consistency (e.g. composite reliability) were determined.

Three hundred (300) questionnaires were directly distributed to SMEs in the manufacturing sector at North Sulawesi. The number of questionnaires is adequate since PLS-SEM has good statistical power although the number size of the samples is limited. Hair et al (2010 2011) indicate that 50 samples are enough.

One hundred and seventy six (176) completed questionnaires were returned thus qualified for analysis, representing an effective response rate of 58.66 percen. Table 2 below shows the profile of survey respondent.

As shown in Table 2, owners and managers of SMEs taking part in this research consist of men (69.31 percen) and women $(29.54 \%)$. The result, which is not different from other regions in Indonesia, (e.g Jogjakarta), shows that men are more predominant as the owners of SMEs than women. (Wuryaningrat 2012). All the participants of this research have a wide range of ages, but their average age is 40 years old. 
Table 2. Profile of survey respondent

\begin{tabular}{llcc}
\hline Dimension & \multicolumn{1}{c}{ Category } & Number of respondent & Percentage \\
\hline \multirow{2}{*}{ Sex : } & a. Man & 122 & 69.31 \\
& b. Woman & 54 & 29.54 \\
& a. $<25$ years & 12 & 6.8 \\
& b. 26-30 years & 13 & 7.4 \\
The age range & c. 31-35 year & 16 & 9.1 \\
& d. 36-40 year & 95 & 54 \\
& e. $>$ 40 year & 40 & 22,7 \\
Education level & a. elementary school & - & - \\
& b. junior high & 6 & 3.41 \\
& c. high school & 87 & 49.43 \\
& d. university level & 83 & 47.16 \\
& a. Craft and clothing & 53 & 30.11 \\
Business line & b. Food and drink & 117 & 66.48 \\
& c. others & 6 & 3.41 \\
Location & a. Village & 25 & 14.20 \\
& b. City & 151 & 85.80 \\
\hline
\end{tabular}

Other interesting results are also shown in Table 2. One of which is the educational level of the owners and managers of SMEs which is considered as high. Data gained show that most owners and managers of SMEs are graduates or either high school or university level with a balanced proportion (49.43\% for high school and $47.16 \%$ for university level). Vinding (2000) in Indarti (2010) explains that education level also serves as a determinant factor in absorptive capacity. The higher the level of education the owners have, the more the SMEs use and assimilate knowledge (Indarti 2010).

Nowadays, North Sulawesi is known as one of Indonesia's interesting tourism destinations and has many famous place to eat. Therefore, the lines of business SMEs in North Sulawesi are dominated by the food and beverages industry, which comprises approximately 66.48 percen of those surveyed.

\section{Validity and Reliability}

After data validation, conducting a statistical test to construct validity is completely necessary. The results of the validity test that only 17 questionnaire questions can be used for collecting data. The other 7 questions cannot be used because their factor loading value is less than 0.5 ; or cross loading problems occur (see Hair et al. 2010). The factor loading scores of 17 items results in AVE values higher than 0.5 , and it means that the value fulfills the required convergent validity (see Hair et al. 2010).

A composite reliability test, as part of convergent validity to measure internal consistency is also conducted (Hair et al. 2010). For all constructs, the value of composite reliability is higher than 0.7. Hair et al. (2010, 2011) mention that an ideal value should be higher than 0.7 . The results of validity and reliability can be seen in Table 3 . 
Table 3. Convergent Validity.

\begin{tabular}{lcccc}
\hline \multirow{2}{*}{\multicolumn{1}{c}{ Variable }} & \multirow{2}{*}{$\begin{array}{c}\text { Number } \\
\text { of item }\end{array}$} & $\begin{array}{c}\text { Factor } \\
\text { loading }\end{array}$ & AVE & $\begin{array}{c}\text { Composite } \\
\text { reliability }\end{array}$ \\
\hline Knowledge donating (KD) & 4 & $0.779-0.800$ & 0.629 & 0.871 \\
Knowledge collecting(KC) & 3 & $0.650-0.771$ & 0.515 & 0.808 \\
Absorptive capacity (ACAP) & 4 & $0.616-0.828$ & 0.558 & 0.788 \\
Innovation capabilities (INOV) & 6 & $0.616-0.840$ & 0.514 & 0.862 \\
\hline
\end{tabular}

Table 4. Total Effect for Hypothesis Result

\begin{tabular}{llccc}
\hline & Relationship & Original sample & S.E & t-stat \\
\hline KD & $\rightarrow$ INOV & 0.167 & 0.057 & 2.924 \\
KC & $\rightarrow$ INOV & 0.135 & 0.061 & 2.217 \\
KD & $\rightarrow$ ACAP & 0.239 & 0.082 & 2.906 \\
KC & A ACAP & 0.193 & 0.082 & 2.359 \\
ACAP $\rightarrow$ INOV & 0.699 & 0.040 & 17.156 \\
\hline
\end{tabular}

Note: KD: knowledge donating, KC: knowledge collecting, ACAP: Absorptive capacity, INOV: innovation capabilities. The result based on total effect (total predictions on direct and indirect effect) PLS output.

Chin (1998) in Hair et al. (2011) mention that discriminant validity should have each indicator which has the highest load, and it needs to be measured. In other words, each indicator must have no cross loading problem. In this research, 17 remaining questionnaires have no cross loading problem. Hence, it can said that the constructs among the four variables of the researches are different, so it is considered acceptable for discriminant validity.

\section{Data Analysis and Result}

Data analysis in this study consists of two major steps, which are, data reduction (validity and reliability) and hypotheses testing. The first step has been conducted and it provides good results. The subsequent step, after testing validity and reliability is testing the hypotheses the results of which are shown in Table 4 and Figure 2. 
Figure 2. Path diagram of conceptualized model

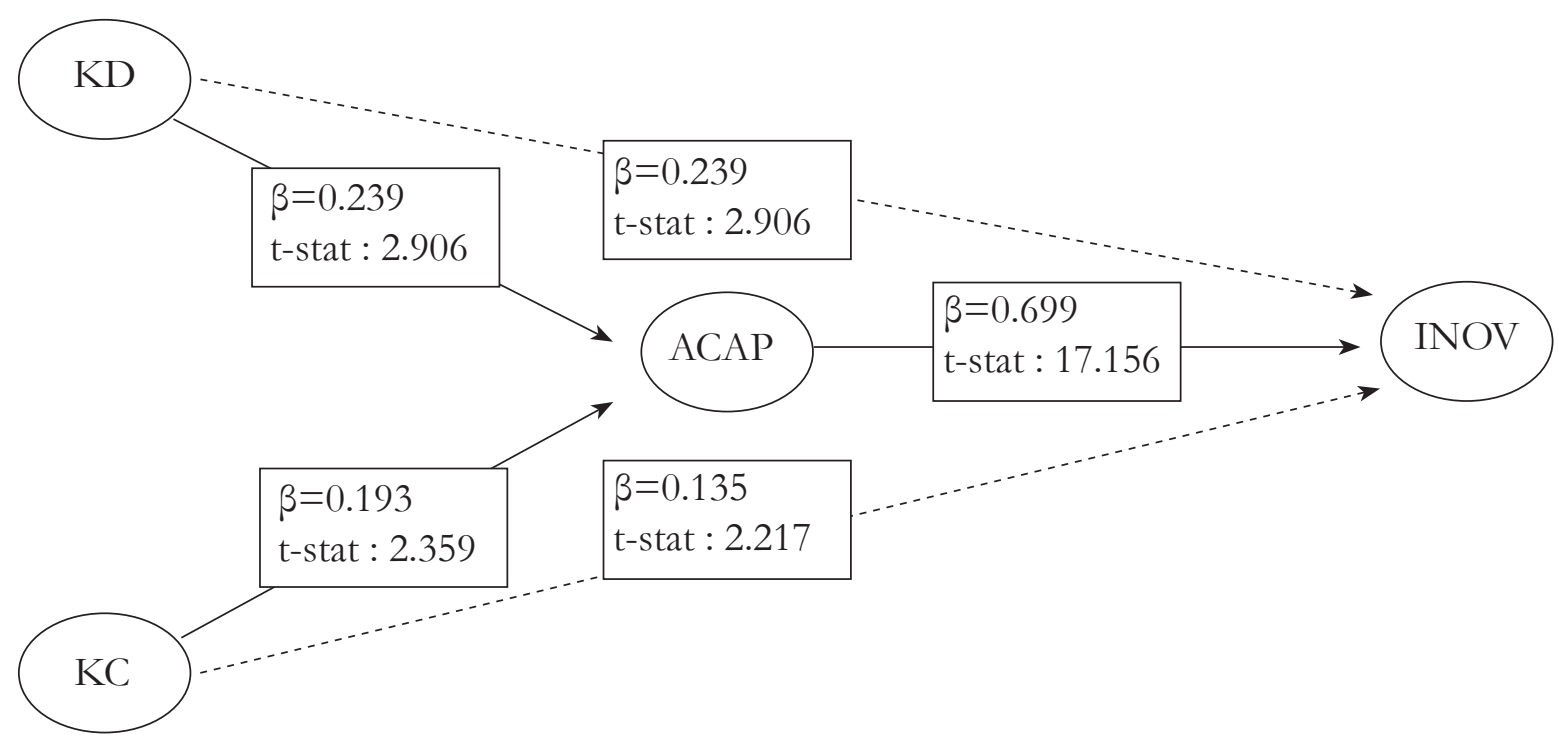

As it can be seen in Table 4, the knowledge donating process has a significant impact on the SMEs' absorptive capacity. The result shows that the $\mathrm{t}$-stat value is equal to 2.906 which is higher than t-stat 1.96, and it is considered to be at significant level. In other words, this finding supports H1a. For $\mathrm{H} 1 \mathrm{~b}$, the finding also supports the hypothesis because its t-stat value is 2.359 which is also higher than 1.96. Thus, it can be concluded that the knowledge collecting process has a significant impact on SMEs' absorptive capacity. From the result of the first hypothesis, it can be concluded that knowledge sharing has a positive impact on SMEs' absorptive capacity.

To test the hypothesis, this research involves a partially mediating effect test, following the recommendation of Baron and Kenny (1986). According to total effect output (see Table 4 and Figure 2), the path coefficient value between knowledge donating (KD) on Innovation capabilities (INOV) produces a path coefficient value of 0.167 . That value decreases from 0.239 (indirect ef- fect) to 0.167 (direct effect) after the implementation of absorptive capacity as a mediating variable. Knowledge collecting (KC) on Innovation capabilities produces a path coefficient value of 0.135 . That value decreases from 0.193 (indirect effect) to 0.167 (direct effect) also after the implementation of absorptive capacity as a mediating variable. The results shown in Table 4 and Figure 2 explain that the direct effect and the indirect effect produce t-stat value higher than 1.96. It this means that the result remains significant after the implementation of absorptive capacity as a mediating variable. From Table 4 and Figure 2, it can also be seen that absorptive capacity has a significant effect on innovation capabilities because it can produce a t-stat value of 17.156 , higher than 1.96. To sum up, absorptive capacity provides significant impact as a mediating variable, but it is not the only factor which mediates the effect between knowledge sharing on innovation capabilities or so it is called partially mediation. In other words, H2 is supported. 


\section{Discussion and Conclusion}

The above results support all hypotheses, which gives a strong indication that capabilities of SMEs to absorb knowledge can be developed to produce innovation through knowledge sharing. Knowledge sharing that includes sharing information, ideas, experiences, skills, advice and input from internal and external sources (Srivastava et al. 2006) could be used by SMEs in the North Sulawesi to increase the ability to absorb knowledge. By having better ability to absorb knowledge, it would be much easier for SMEs to transform knowledge into innovative forms.

The above results can be analogized with students having scientific discussions before solving their task. By involving them in many intellectual discussions, the students' ability can be shaped from knowing nothing into having good understanding, and from having good understanding into having better comprehension. Increasing intellectual capacity leads to better management in overcoming workloads and achieving job targets. Knowledge sharing enables SMEs to continue learning so their abilities can flourish. SMEs which intend to continue learning appear to be more innovative becoming sustainable competitive advantage (Johannessen et al. 2001). Through knowledge sharing, the capability of SMEs to absorb knowledge can be developed, so any weaknesses that SMEs have in the field of human resources (i.e. intellectual capital, human capital) can be gradually resolved.

These results support previous research such as Liao et al. (2006) and Tsai (2001) which reveals that organizations could be more innovative through knowledge sharing, capabilities of individuals and knowledge absorption. In addition, the results of this study support the concept of Davenport and Prusak (1998) and Indarti (2010) who state that knowledge sharing without the ability to absorb knowledge will be useless and will not be able to bring innovations.

Therefore, this study emphasizes that SMEs in the North Sulawesi are expected to continue learning through knowledge sharing with different sources of knowledge such as employees, customers, and suppliers as well as other institutions such as academics and even government. In addition, policy makers and educational institutions could provide facilities for the SMEs to gain access to knowledge in the an effort to have more interaction with knowledge sources. Indarti (2010) mentions that the higher interaction (knowledge sharing) among knowledge sources (e.g. Supplier, consumer, competitor, employees, government, other institutions), the higher the SMEs' absorptive capacity is.

Through the learning process, SMEs can create the climate of learning in one organization. Politis (2002) explains that organizational learning, a climate of creativity can support an innovative environment in an organization and in the practices of creative economy in North Sulawesi.

Either small or big companies can survive by undertaking creative and innovative efforts, particularly SMEs. An innovative SME needs to make efforts to develop its entrepreneurial intensity in order to strengthen or develop its business. The development of an SME's entrepreneurial intensity can be shown by looking at more information, learning more, and having discussions with all organizational elements. These efforts are in line with the concepts of creative economics which try to intensify information and creativity by relying on ideas and stocks of knowledge. 
Knowledge sharing from various sources of knowledge is one way for the business owner to improve his stock of knowledge. It involves learning or acquiring knowledge, experiences, and skills which are important for SMEs to provide innovation in every business step. This opinion is also suitable for business owners in North Sulawesi. If the sources of knowledge such as suppliers, costumers, educational institutions and others, can work together harmoniously in one community, the learning process of SMEs will run better. Knowledge sharing serves as a learning process which gives SMEs' better absorptive capacity. Higher absorptive capacity ensures SMEs achieve a better stock of knowledge and ideas which eventually leads to better innovation and sustainable competitive power.

The main goal of the discussion above is to establish a formal, informal or virtual community. The members of this community are the the SMEs themselves, their loyal customers, key suppliers, educational institutions and other institutions such as banks and cooperatives, to provide a foundation, training, and funding. Through the community, SMEs can continuously learn from many activities such as exchange of ideas, offering ideas, suggestions, giving feedback and even complaints which are intended to increase SMEs' ability and insight to create innovative approaches.

\section{Limitations and Further Research Suggestions}

Like any other empirical study, this research also has its own limitations. The first limitation lies in the choice of a cross-section- al survey. A cross sectional survey is considered as having drawbacks because knowledge sharing, absorptive capacity, and innovation capabilities refers to a continuous learning process. Hence, the selection of a cross-sectional survey may not be able to explain the phenomenon as a whole because the data are taken only at a certain time. Thus, it needs longitudinal studies to in help establish the causal relationship between constructs of interest in this research.

The second limitation of this study is that the construct is based solely on the subjective perceptions of SMEs' owners and managers. Although this approach was the most suitable in the research context, it may lead to bias. Future research can consider measuring innovation based on other objective aspects, such as patents or other objective innovation outputs. The distribution of the questionnaires is done by giving this questionnaire directly to target respondents. This is to ensure that the questionnaire is given to the right subjects in order to avoid bias.

Although absorptive capacity is able to increase through knowledge sharing as a learning process, someone will still have limitations in absorbing a lot of knowledge available. Future researchers are encouraged to involve other variables, for example, age, organizational culture and organizational trust in order to provide a better perspective on the phenomenon of innovation. 


\section{References}

Acs, Z.J., R. Morck, J.M. Shaver and B. Yeung. 1997. The Internationalization of Small and Medium-Sized Enterprises: A Policy Perspective. Small Business Economics (9): 7-20.

Ayyagari, M. 2006. Micro and small enterprises: unexplored pathways to growth. US AID working paper. The Iris Center, University of Maryland,

Bagozzi, R.P., and U.M. Dholakia. 2002. Intentional Social Action in Virtual Communities. Journal of Interactive Marketing (16): 2-21.

Barney, J.B. 2007 Gaining and Sustaining Competitive Advantage (3 ${ }^{\text {rd }}$ edition), New Jersey, Prentie-Hall.

Baron, R.M., and Kenny D, A. 1986. The Moderator-Mediating variable distinction in social pyschological research. Journal of Personality and Social Pyschology, 51(6): 1173-1182

Bartol, K.M. and A. Srivastava. 2002. Encouraging knowledge sharing: the role of organizational reward system. Journal of Leadership and Organizations Studies (9): 64-76.

Chaudhry, A.S. 2005. Knowledge sharing practices in Asian institutions: a multi-cultural perspective from Singapore, Proceedings of the 7th IFLA General Conference and Council of the World Library and Information Congress, Oslo, Norway.

Cohen, W.M., and Levinthal, D.A. 1990. Absorptive capacity: A new perspective on learning and innovation. Administrative Science Quaterly (35): 128-152.

Covin, J.G., and M.P. Miles. 1999. Corporate Entrepreneurship and the Pursuit of Competitive Advantage. Entrepreneurship: Theory and Practice (23): 105-120.

Dalkir, K. 2005. Knowledge Management in Theory and Practice. Oxford, UK: Burlington, MA.

Davenport, T.H. and L. Prusak. 1998. Working Knowledge: How Organizations Manage What They Know. Harvard Business School Press, Boston, MA.

Dyer, J.H, and K. Nobeoka. 2000. Creating and managing a high-performance knowledge sharing network: The Toyotacase. Strategic Management Journal (21): 345-368.

Grant, R.M. 1996. Toward a knowledge-based theory of the firm.Strategic Management Journal (17): 109122.

Hair, J.F, M. Sarstedt, C.M. Ringle, and J.A. Mena. 2011. An assessment of the use of partial least squares structural equation modeling in marketing research. Academic of Marketing Science (10): 1-20.

Hair, J.F., A.R.L., Tatham, and W.C., Black. 2010. Multivariate Data Analysis: Global Perspective (7 $7^{\text {th }}$ edition). New Jersey: Prentice Hall.

Indarti, N. 2010. The Effect of Knowledge Stickiness and Interaction on Absorptive Capacity: Evidence from furniture and software Small and Medium Enterprises in Indonesia. Dissertation (unpublished). Groningen: University of Groningen.

Johannessen, J.A., B. Olsen, and G.T. Lumpkin. 2001. Innovation as newness: What is new, how new, and new to whom?.European Journal of Innovation Management (4): 20-31.

Kamasak, R., and F. Bulutlar. 2010. The influence of knowledge sharing on innovation. European Business Review (22): 306-317. 
Kerlinger F.N., and H.B. Lee. 2000. Foundation of Behavioral Research (4th edition). Harcourt College Publisher.

Lam, A., Lambermont-Ford. 2010. Knowledge sharing in organizational contexts: a motivation-based perspective. Journal of Knowledge Management (14): 51-66.

Liao, S., W.C. Fei, and C.C. Chen. 2007. Knowledge sharing, absorptive capacity, and innovation capability: an empirical study of Taiwan's knowledge intensive industries. Journal of Information Science (33): 340-359.

March, J.G. 1991. Exploration and exploitation in organizational learning, Organization Science 2: 71-87.

Mead, D.C. and C. Liedholm. 1998. The dynamic of micro and small enterprises in developing countries. World Development (26): 61-74.

Nonaka, I. and H. Takeuchi. 1995. The Knowledge-Creating Firm: How Japanese Companies Create the Dynamics of Innovation. New York: Oxford University Press.

Nonaka, I., G.V. Krogh and S. Voelpel. 2006. Organizational knowledge creation theory: evolutionary paths and future advances. Organization Studies (27): 179-208.

Pelham, A.M. 2000. Marketing orientation and other potential influences on performance in small and medium-sized manufacturing firms. Journal of Small Business Management (38): 48-67.

Pirich, A., S. Knuckey, and J. Campbell. 2001. An interface between entrepreneurship and innovation: New Zealand SMEs perspective. DRUID Nelson and Winter Conference.

Politis, J.D. 2002. Transformational and transactional leadership predictors of the 'Stimulant' determinants to creativity in organisational work environments. Electronic Journal of Knowledge Management (2): 23-34.

Rogers, E.M. 2003. Diffusion of innovations. New York: Free Press.

Srivastava, A., K.M. Bartol, and E.A. Locke. 2006. Empowering leadership in management teams: Effects on knowledge sharing, efficacy, and performance. Academy of Management Journal (49): 1239-1251

Sveiby, K. 2001. A knowledge based theory of the firm to guide in strategy formulation. Journal of Intelectual Capital (2): 344-358.

Tidd, J. and J. Bessant, K. 2005. Managing Innovation: Integrating Technological, Market and Organizational Change. Chichester: John Wiley \& Sons.

Tsai, W. 2001. Knowledge transfer in intraorganizational network: Effect of network position and absorptive capacity on business unit innovation and performance. Academy of Management Journal (44): 996-1004.

Van den Hooff, B. and J.A. de Ridder. 2004. Knowledge sharing in context: the influence of organizational commitment, communication climate and CMC use on knowledge sharing. Journal of Knowledge Management (8): 117-30.

Wiklund, J. and D. Shepherd. 2003. Knowledge-based resources, entrepreneurial orientation and the performance of small and medium-sized businesses. Strategic Management Journal (24): 1307-1314

Wuryaningrat, N.F. 2012. The effect of leadership and knowledge sharing on innovation capabilities: study at small and medium enterprises in Province of Daerah Istimewa Yogyakarta. Thesis (unpublished). Gadjah Mada University, Indonesia. 